\title{
Digestive diseases of cattle diagnosed at the "Clínica de Bovinos de Garanhuns"-UFRPE: retrospective study and influence of seasonality ${ }^{1}$
}

\author{
Gliére S.L. Soares ${ }^{2 *}$ (D), Nivaldo A. Costa ${ }^{3}$, José Augusto B. Afonso ${ }^{3}$, Maria I. Souza ${ }^{3}$,
} Jobson F.P. Cajueiro ${ }^{3}$, Jean C.R. Silva ${ }^{4}$, Fernando Ferreira ${ }^{5}$ (D) and Carla L. Mendonça ${ }^{3}$

\begin{abstract}
Soares G.S.L., Costa N.A., Afonso J.A.B., Souza M.I., Cajueiro J.F.P., Silva J.C.R., Ferreira F. \& Mendonça C.L. 2021. Digestive diseases of cattle diagnosed at the "Clínica de Bovinos de Garanhuns"-UFRPE: retrospective study and influence of seasonality. Pesquisa Veterinária Brasileira 41:e06800, 2021 Clínica de Bovinos de Garanhuns, Universidade Federal Rural de Pernambuco, Av. Bom Pastor s/n, Boa Vista, Garanhuns, Cx. Postal 152, PE 55292-272, Brazil. E-mail: glieresoares87@gmail.com

Diseases of the bovine digestive system make up an important group of diseases, often being responsible for significant economic losses in the livestock sector. The current work aimed to carry out a retrospective study of the diseases of the digestive system in cattle diagnosed at the "Clínica de Bovinos de Garanhuns", "Universidade Federal Rural de Pernambuco", from January 1999 to December 2018. In this period, a total of 9,343 cattle were admitted to the CBG-UFRPE, of which 2,238 (24.0\%) were diagnosed with diseases of the digestive system. In two decades, the total number of cattle admitted annually by the institution almost doubled as well as the number of cases of digestive diseases. The diseases categorized as mechanical/ motor were the most prevalent (33.6\%), followed by fermentative $(28.4 \%)$, gastroenteritis $(16.0 \%)$, esophageal diseases (9.7\%), and diseases of the oral cavity (4.5\%). Lesions of the rectum and anus, congenital alterations, and other digestive diseases showed relative frequencies below 4\%. Traumatic reticulitis and its sequelae (14.5\%) are the most prevalent disorders, followed by simple indigestion (10.1\%), esophageal and intestinal obstructive disorders (9.0\%), non-specific gastroenteritis (8.6\%), displaced abomasum (RDA and LDA) (5.5\%), and frothy bloat, ruminal lactic acidosis, and impaction of the forestomach and abomasum, which represented approximately $5 \%$ each. In general, these diseases presented a lethality rate of $46.0 \%$, with emphasis on mechanical/motor diseases with a lethality rate of $73.8 \%$. In general, diseases were more prevalent in females, crossbreeds, aged over 24 months, and raised in a semi-intensive system. Diseases of the digestive system increased over the years studied, representing a considerable portion of the diseases that affect cattle raised in this region, which makes up the main milk basin in the State of Pernambuco, confirming its economic and social impact in the region.
\end{abstract}

INDEX TERMS: Digestive diseases, retrospective study, gastrointestinal tract, mechanical/motor diseases, fermentative diseases, seasonality, cattle.

\footnotetext{
${ }^{1}$ Received on January 9, 2021.

Accepted for publication on February 16, 2021.

Part of the Doctoral Thesis of the first author, who receives a scholarship from CAPES.

${ }^{2}$ Graduate Program in Veterinary Medicine, Universidade Federal Rural de Pernambuco (UFRPE), Rua Dom Manoel de Medeiros s/n, Campus Dois Irmãos, Recife, PE 52171-900, Brazil. *Corresponding author: glieresoares87@gmail.com

${ }^{3}$ Clínica de Bovinos de Garanhuns, Universidade Federal Rural de Pernambuco (UFRPE), Av. Bom Pastor s/n, Boa Vista, Cx. Postal 152, Garanhuns, PE 55292-272, Brazil.

${ }^{4}$ Departamento de Medicina Veterinária, Universidade Federal Rural de Pernambuco (UFRPE), Rua Dom Manoel de Medeiros s/n, Campus Dois Irmãos, Recife, PE 52171-900, Brazil.

${ }^{5}$ Departamento de Medicina Veterinária Preventiva e Saúde Animal, Faculdade de Medicina Veterinária e Zootecnia (FMVZ), Universidade de São Paulo (USP), Rua Professor Orlando Marques Paiva 87, Butantã, São Paulo, SP 05508-270, Brazil.
}

RESUMO.- [Enfermidades do sistema digestório de bovinos diagnosticadas na Clínica de Bovinos de Garanhuns-UFRPE: estudo retrospectivo e influência da sazonalidade.] As enfermidades do sistema digestório dos bovinos compõem importante grupo de doenças frequentemente responsáveis por perdas econômicas significativas no setor pecuário. Este trabalho teve por objetivo realizar um estudo retrospectivo das enfermidades do sistema digestório dos bovinos diagnosticadas na Clínica de Bovinos de Garanhuns, Universidade Federal Rural de Pernambuco, no período de janeiro de 1999 a dezembro de 2018. Neste período foi atendido um total de 9.343 bovinos dos quais $2.238(24,0 \%)$ foram diagnosticados com enfermidades do sistema digestório. Em duas décadas, o 
número total de bovinos atendidos anualmente pela instituição quase dobrou, assim como o número de casos de doenças digestivas. As enfermidades categorizadas como de natureza mecânica/motora foram as mais prevalentes $(33,6 \%)$, seguidas das fermentativas $(28,4 \%)$, das gastroenterites $(16,0 \%)$, das enfermidades esofágicas $(9,7 \%)$ e das enfermidades da cavidade oral $(4,5 \%)$. As lesões do reto e ânus, as alterações congênitas e outras enfermidades digestórias apresentaram frequências relativas inferiores a 4\%. As reticulites traumáticas e suas sequelas $(14,5 \%)$ destacaram-se como as doenças mais prevalentes, seguidas das indigestões simples $(10,1 \%)$, dos transtornos obstrutivos esofágicos e intestinais $(9,0 \%)$, das gastroenterites inespecíficas (8,6\%), dos deslocamentos de abomaso (DAD e DAE) (5,5\%) e do timpanismo espumoso, acidose láctica ruminal e compactações dos pré-estômagos e abomaso, que representaram aproximadamente $5 \%$ cada. No geral estas enfermidades apresentaram taxa de letalidade de 46,0\%, com destaque para as enfermidades de natureza mecânica/motora cuja letalidade foi de 73,8\%. De maneira geral as enfermidades foram mais prevalentes em fêmeas mestiças, com idade superior a 24 meses, criadas em sistema semi-intensivo. As enfermidades do sistema digestório, crescentes ao longo dos anos estudados, representaram parcela considerável das doenças que acometem os bovinos criados na região que compõe a principal bacia leiteira do Estado de Pernambuco, ratificando seu impacto econômico e social para a região.

TERMOS DE INDEXAÇÃO: enfermidades digestivas, estudo retrospectivo, trato gastrointestinal, doenças de natureza mecânica/motora, doenças fermentativas, sazonalidade, bovinos.

\section{INTRODUCTION}

Disorders of the digestive system of ruminants include a group of important diseases and are responsible for major economic losses in different regions of Brazil and the world (Dharmaceelan et al. 2012, Lira et al. 2013, Sharma et al. 2015, Afonso 2017, Pawaiya et al. 2017, Santos et al. 2017). Most of these disorders are related to inadequate nutritional management due to the supply of food in inappropriate quantity or quality (Marques et al. 2018).

In Brazil, particularly in the Northeast region, characterized by a semi-arid climate, prolonged periods of irregular distribution of rainfall play an important role in triggering digestive disorders in cattle. This is due not only to the lack of forage, but also to the quality of alternative feed sources commonly used in animal diets, and the excessive supply of diets rich in concentrates, especially observed in properties with a higher degree of intensification of the production system (Câmara et al. 2009, Coutinho et al. 2012, Helayel et al. 2012, Nascimento et al. 2016).

Studies based on data collection from hospital archives are considered an important epidemiological tool since they allow systematic knowledge of the clinical, laboratorial, and epidemiological characteristics of the various diseases that affect different animal species, as well as humans (Gopal et al. 2015, Bezdekova \& Janalik 2016, Eshetu et al. 2018, LawsonAnanissoh et al. 2018, Kachhawa et al. 2019). In addition, this type of study enables the establishment of the occurrence of a certain disease according to characteristics related to the animal, such as breed, sex, and age group, as well as according to demographic and seasonal distribution (Thrusfield 2005).
In Brazil, in the last decade, several retrospective studies, based on clinical and/or anatomicall pathological data, were carried out in different regions, with the objective of establishing the occurrence of the main diseases that affect cattle according to the different organic systems (Lucena et al. 2010, Burns et al. 2013, Rondelli et al. 2017, Borowsky et al. 2019, Oliveira et al. 2019, Pupin et al. 2019). These studies demonstrated regional variation in the occurrence of diseases affecting the digestive system of cattle, and often classify them by etiology into nutricional and metabolic diseases. These diseases were responsible for approximately $10 \%$ of the clinical cases of ruminants attended at the Veterinary Teaching Hospital of the "Universidade Federal do Rio Grande do Sul" (UFRGS; 6/60) (Borowsky et al. 2019), as well as at the Bovine and Small Ruminant Hospital of the "Faculdade de Medicina Veterinária e Zootecnia", "Universidade de São Paulo" (USP; 9/88) (Tortorelli et al. 2012) and 21\% (74/351) of the clinical cases of admitted treated at the Veterinary Hospital of the "Escola deMedicina Veterinária e Zootecnia" at the "Universidade Federal do Tocantins" (Oliveira et al. 2019). In the State of Pernambuco, Afonso (2017) reported that diseases of the bovine digestive system represent approximately $18 \%$ of the cases at the "Clínica de Bovinos de Garanhuns", "Universidade Federal Rural de Pernambuco" (CBG-UFRPE).

In addition to these comprehensive studies, several specific studies, such as reports or case series, addressing specific diseases of the forestomach (Coutinho et al. 2009, Dalto et al. 2009, Nascimento et al. 2016), abomasum (Borges et al. 2007, Câmara et al. 2009, 2010, Mesquita et al. 2012, Silva Filho et al. 2012, Gonçalves et al. 2018), and intestines (Afonso et al. 2002, 2008, Silva Filho et al. 2010, Câmara et al. 2016) were also carried out in the country.

However, when considering epidemiological studies that fully encompass the digestive tract and its respective diseases, these are scarce in Brazil, with only the study of Marques et al. (2018), in which clinical and necropsy records of 233 cattle were analyzed over a period of 14 years at the Veterinary Hospital of the "Universidade Federal de Campina Grande" (HV-UFCG), Patos, Paraíba.

Therefore, considering the important socioeconomic role that cattle prodution play in the State of Pernambuco, especially for the immediate region of Garanhuns, where the main dairy basin of the state is located, combined with the high incidence of diseases as an important factor responsible for influencing animal productivity. This study aims to to establish the different digestive diseases diagnosed in cattle in the region, as well as their distribution regarding as breed, sex, age, and management system, and the influence of seasonality on their occurrence.

\section{MATERIALS AND METHODS}

A retrospective study of the diseases that affect the digestive system of cattle was carried out from the descriptive analysis of the clinical records of the "Clínica de Bovinos de Garanhuns", Campus of the "Universidade Federal Rural de Pernambuco", from January 1999 to December 2018, totaling 20 years. Only data from hospital care were included in the study, excluding the field clinical care carried out in loco at the farms. According to the hospital protocol, all animals were submitted to clinical examination (Dirksen 1993), and the information was filled out in the medical record (anamnesis, clinical examination, and complementary tests), following the same completion protocol. 
The diagnosis of each disease was established based on the general physical examination and specific examination of the digestive system, associated with complementary tests (clinical patology and imaging) and the anatomopathological examination, when death occurred.

Initially, the screening of clinical cases related to the digestive system was carried out by consulting the Institution's Record Books, from 1999 to 2018. Subsequently, the medical records were retrieved for the collection of information and preparation of the Database, using the software Microsoft Excel $2013^{\circledR}$.

Data were collected with respect to sex (female or male); breed (pure or crossbreed); age group ( 0 to 24 months and above 24 months); management system (semi-intensive, intensive, and extensive); area of origin of the animals (state, municipality, and geographic region); therapeutic conduct (clinical, clinical-surgical, and unviable), and the outcome (hospital discharge, natural death, euthanasia, and indication for slaughter). From this information, lethality [(number of deaths/number of patients)x100] was calculated for each disease, considering death as all animals that died naturally, were euthanized (due to the severity of the case), or were sent to slaughter.

For the study of seasonality, the period from September to March was considered the dry period, with a mean monthly rainfall less than $75 \mathrm{~mm}$ (min. 10.3mm-Nov./max. 70.4mm-Mar.), and the rainy period as from April to August with a mean monthly rainfall greater than 75mm (min. 78.1mm-Apr./max.157.2mm-Jun.). This criterion was defined based on the evaluation of rainfall in the region, over the 20 years studied, using the database of the "Instituto Nacional de Meteorologia” (INMET), experimental station 82893, Garanhuns/PE.

The diagnosed diseases were conveniently grouped according to the type of dysfunction into: oral cavity diseases, esophageal diseases, fermentative diseases, mechanical/motor diseases, gastroenteritis, lesions of the rectum and anus, congenital alterations, and other diseases which were not classified in the previous categories.

For the analysis of the data, the descriptiva statistical model was used, observing the distribution of the data through the relative and absolute frequencies of the main disorders. A total of 72 medical records were excluded from the analysis as they were incomplete with regard to some information considered essential (Thrusfield 2005).

The analysis of decomposition of time series by the multiplicative model was performed with data of monthly rainfall and the frequency of cases diagnosed monthly over the 20 years. Subsequently, the correlation between these variables was estimated by calculating the Pearson coefficient and the significance obtained by the linear correlation assessed according to Little \& Hills (1978). The level of significance adopted for the analyses was $5 \%$ and these were carried out using the statistical program MINITAB $18^{\circledR}$.

\section{RESULTS}

It was found that during the 20 years corresponding to the period studied, the institution attended, in the inpatient system, a total of 9,343 cattle, of which 2,238 (24.0\%) were diagnosed with diseases of the digestive system. In two decades, the total number of cattle admitted annually by the institution almost doubled as well as the number of cases of digestive diseases (Fig.1).

Mechanical/motor diseases presented a frequency of $33.6 \%$ $(n=752)$, followed by fermentative diseases $28.4 \%(n=635)$, gastroenteritis $16.0 \%(n=357)$, esophageal diseases $9.7 \%$ $(n=216)$, and oral cavity diseases $4.5 \%(n=100)$. The other categories, lesions of the rectum and anus, congenital alterations in the digestive system, and other diseases presented relative frequencies below $4 \%$ of the total number of diagnosed cases (Table 1). The table also presents the distribution of diseases according to the therapeutic procedure performed and the lethality presented for each group of disease.

Clinical treatment was provided in $54.7 \%$ of the cases, while $23.2 \%$ of the animals were submitted to both clinical and surgical procedures. For $22 \%$ of the studied patients, the recommended therapy was considered unfeasible to be performed due to the severity of the clinical condition, which is often not economically viable for the rural producer. In these cases, according to the clinical status and body score, the animals were either destined for animal slaughter or euthanized.

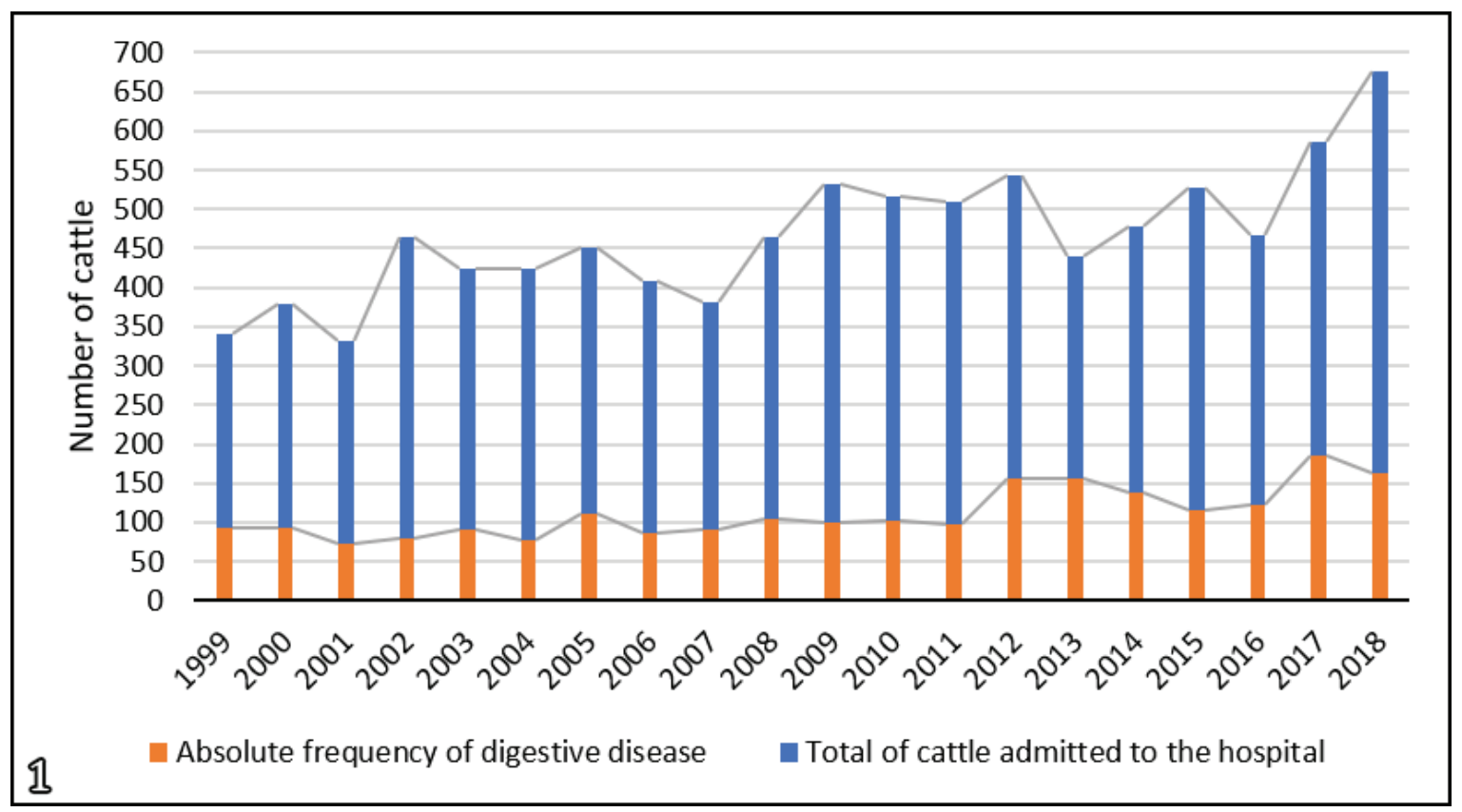

Fig.1. Total number of cattle admitted annually and absolute frequency of digestive diseases of cattle diagnosed at CBG-UFRPE from 1999 to 2018. 
Table 1. Absolute (n) and relative (\%) frequency, therapeutic treatment, and lethality rate of the digestive disease of cattle diagnosed at CBG-UFRPE $(n=2238)$ from January 1999 to December 2018

\begin{tabular}{|c|c|c|c|c|c|c|}
\hline \multirow{2}{*}{ Categories/Diseases } & \multirow{2}{*}{$\mathrm{n}$} & \multirow{2}{*}{$\%$} & \multicolumn{3}{|c|}{ Therapeutic treatment $^{\mathrm{b}}$} & \multirow{2}{*}{$\begin{array}{c}\text { Lethality } \\
(\%)^{\mathrm{b}}\end{array}$} \\
\hline & & & Clinical (\%) & Surgical (\%) & Unviable (\%) & \\
\hline Diseases of the oral cavity & 100 & 4.5 & 94.4 & 1.1 & 4.4 & 18.6 \\
\hline Stomatitis & 30 & 1.3 & & & & 21.4 \\
\hline Actinomycosis & 29 & 1.3 & & & & 21.4 \\
\hline Actinobacillosis & 22 & 1.0 & & & & 9.1 \\
\hline Pharyngitis & 18 & 0.8 & & & & 22.2 \\
\hline Periodontitisv & 1 & 0.0 & & & & 0.0 \\
\hline Esophageal diseases & 216 & 9.7 & 91.7 & 2.4 & 5.9 & 26.1 \\
\hline Obstruction & 201 & 9.0 & & & & 23.5 \\
\hline Esophageal diverticulum & 6 & 0.3 & & & & 33.3 \\
\hline Megaesophagus & 5 & 0.2 & & & & 80.0 \\
\hline Esophagitis & 4 & 0.2 & & & & 75.0 \\
\hline Diseases of a fermentative nature & 635 & 28.4 & 61.4 & 33.0 & 5.6 & 20.8 \\
\hline Simple indigestion & 226 & 10.1 & & & & 3.2 \\
\hline Displaced abomasum & 124 & 5.5 & & & & 28.9 \\
\hline Frothy bloat & 109 & 4.9 & & & & 19.4 \\
\hline Ruminal lactic acidosis & 105 & 4.7 & & & & 33.3 \\
\hline Cecum dilation & 64 & 2.9 & & & & 48.4 \\
\hline Ruminal alkalosis & 7 & 0.3 & & & & 28.6 \\
\hline Diseases of a mechanical/motor nature & 752 & 33.6 & 31.5 & 24.6 & 43.9 & 73.8 \\
\hline Traumatic reticulitis and its sequelae & 324 & 14.5 & & & & 87.4 \\
\hline Obstructive intestinal disorders & 200 & 8.9 & & & & 73.5 \\
\hline Impaction forestomachs and abomasum & 100 & 4.5 & & & & 49.0 \\
\hline Vagal indigestion & 90 & 4.1 & & & & 61.6 \\
\hline Gaseous tympanism & 21 & 0.9 & & & & 25.0 \\
\hline Various mechanical alterations ${ }^{a}$ & 17 & 0.8 & & & & 82.4 \\
\hline Gastroenteritis & 357 & 16.0 & 78.0 & 2.6 & 19.0 & 50.1 \\
\hline Nonspecific & 193 & 8.6 & & & & 39.0 \\
\hline Parasitic & 82 & 3.7 & & & & 49.4 \\
\hline Ulcerative & 82 & 3.7 & & & & 75.6 \\
\hline Diseases of the rectum and anus & 18 & 0.80 & 31.3 & 37.5 & 31.3 & 44.4 \\
\hline Stenosing lesions & 5 & 0.2 & & & & 40.0 \\
\hline Lacerating lesions & 5 & 0.2 & & & & 80.0 \\
\hline Rectum prolapse & 3 & 0.1 & & & & 33.3 \\
\hline Proctitis & 2 & 0.1 & & & & 0.0 \\
\hline Meconium retention & 2 & 0.1 & & & & 50.0 \\
\hline Anus neoplasm & 1 & 0.0 & & & & 0.0 \\
\hline Congenital alterations & 73 & 3.3 & 2.9 & 82.6 & 14.5 & 24.7 \\
\hline Anal atresia & 65 & 2.9 & & & & 18.0 \\
\hline Rectum agenesis & 4 & 0.2 & & & & 75.0 \\
\hline Colon agenesis & 3 & 0.1 & & & & 100.0 \\
\hline Cleft lip & 1 & 0.0 & & & & 100.0 \\
\hline Other disorders & 87 & 3.9 & 6.8 & 51.4 & 41.9 & 66.3 \\
\hline Peritonitis $^{c}$ & 26 & 1.2 & & & & 96.2 \\
\hline Eventration & 23 & 1.0 & & & & 52.2 \\
\hline Incarceration of abomasum in hernia & 22 & 1.0 & & & & 28.6 \\
\hline Evisceration & 16 & 0.7 & & & & 87.5 \\
\hline TOTAL & 2238 & 100 & 54.7 & 23.2 & 22.1 & 46.0 \\
\hline
\end{tabular}

${ }^{a}$ Ruminal atony ( $\left.n=1\right)$, torsion of the abomasum ( $\left.n=1\right)$, traumatic jejunitis ( $\left.n=2\right)$, paralytic ileus ( $\left.n=3\right)$, colon impaction ( $\left.n=3\right)$, bowel loop rupture (n=7); ${ }^{\mathrm{b}}$ one hundred and twelve (112) medical records did not contain information on the therapeutic treatment and 51 did not contain information on the outcome; ${ }^{c}$ not related to digestive tract diseases. 
With respect to lethality, in general the diseases that affect the digestive system of cattle showed a rate of $46.0 \%$. Among the groups, mechanical/motor diseases presented the highest lethality rate $(73.8 \%)$, with emphasis on traumatic reticulitis (87.3\%) and obstructive intestinal disorders (73.5\%).

In general, diseases of the digestive system affected mainly females $(79.2 \%)$, crossbreeds $(72.1 \%)$, aged over 24 months $(70.7 \%)$ (Table 2), reared in a semi-intensive system $(68.0 \%)$, and during the dry period of the year (62.7\%) (Table 3).

Among the main feed included in the diet of the animals studied were ration feed (mixture of corn bran, soy, cotton, and wheat), palm (Opuntia sp.), pasture (native or formed mainly of Brachiaria sp. or Digitaria decumbens), Pennisetum purpureum, cassava (Manihot esculenta) peels, corn silage, industrial waste (brewery and Saccharum officinarum bagasse), and $S$. officinarum in natura. In addition, chicken litter has also been reported as a constituent in the diet of approximately $7 \%$ of the animals. Of the medical records analyzed, $8 \%(173 / 2166)$ did not contain information on the type of feed provided.

The Figure 2 shows the spatial distribution of the cases, highlighting the municipalities of origin of the animals according

Table 2. Relative (\%) and absolute distribution according to sex, breed, and age category of the digestive disease of cattle diagnosed at CBG-UFRPE $(n=2166)$ from January 1999 to December 2018

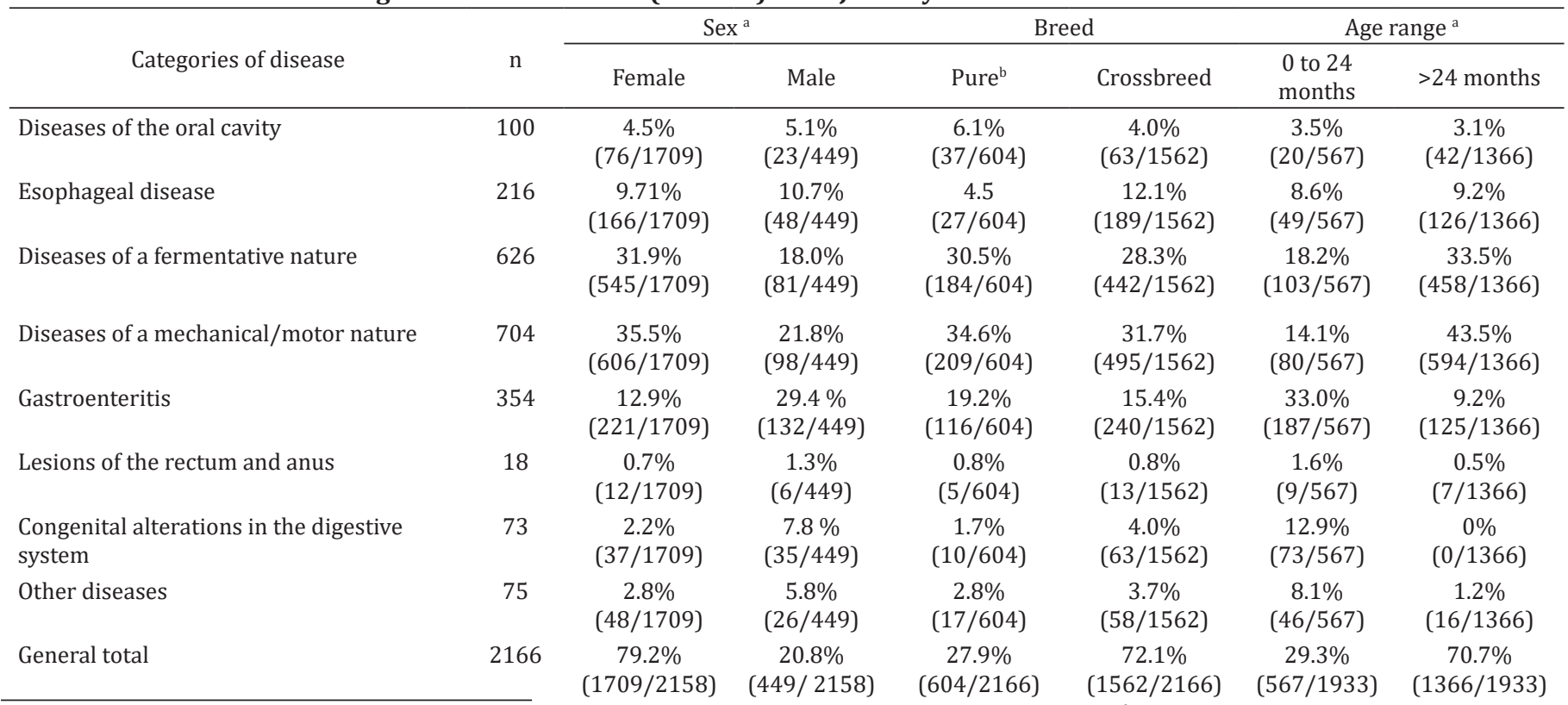

${ }^{a}$ Eight medical records did not contain information about sex and 233 did not contain information about age; ${ }^{b}$ Holstein, Nellore, Gir, Swiss-Brown, Jersey, Guzerá, Sindhi, Simmental, Pitangueira, Santa Rosalia, and Charolais.

Table 3. Relative (\%) and absolute distribution according seasonality and management system of the digestive disease of cattle diagnosed at CBG-UFRPE (n=2166) from January 1999 to December 2018

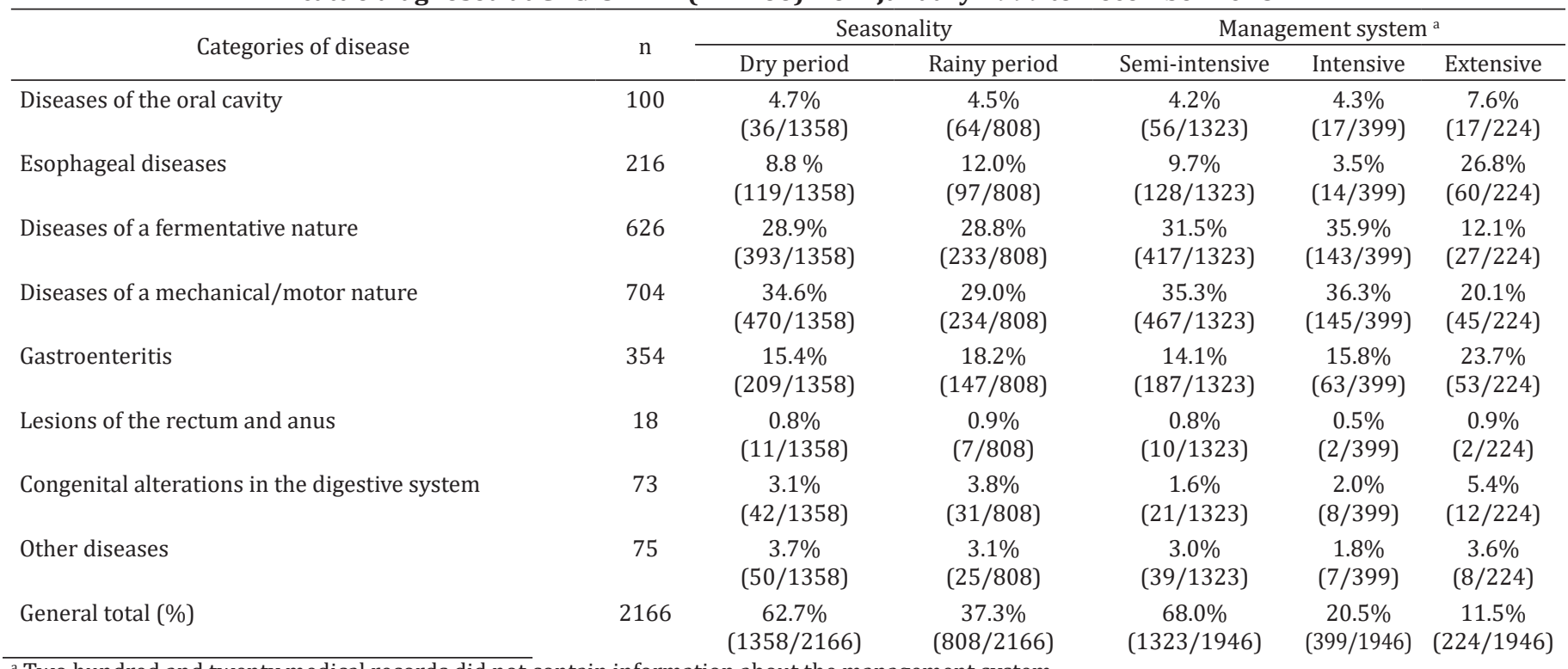

$\overline{\mathrm{a}}$ Two hundred and twenty medical records did not contain information about the management system. 
to their frequency. A total of 79 municipalities in the states of Pernambuco, Alagoas, and Paraíba sent animals to the institution for clinical and hospital care during the period studied. The highest frequency of demand for services was observed among municipalities in the state of Pernambuco, which make up the immediate regions of Garanhuns $57.9 \%$ (1269/2192), Arcoverde 26.6\% (584/2192), and Belo Jardim Pesqueira 8.9\% (195/2192), and from Alagoas municipalities $1.7 \%(38 / 2192)$, close to the border with the State of Pernambuco. The municipalities of Garanhuns, Pedra, Venturosa, and São Bento do Una were responsible for sending almost half (46.9\%) of the animals attended at the institution during the period studied. Approximately $2 \%$ $(56 / 2238)$ of the medical records did not have information about the municipality of origin of the animals.

In the analysis of decomposition of time series for the frequency of cases of disorders of the digestive system of cattle and for rainfall in the studied period, an increasing trend was observed for the frequency of cases and a decreasing trend for rainfall (Fig.3 and 4). In addition, seasonal fluctuations were identified in both data sets, given that the seasonal indices were above or below the mean at different times (Fig.5 and 6).

Transforming the seasonal indices into percentages, it can be seen that in the months of May, June, July, and August when the rainfall exceeded the mean by up to $109 \%$, the frequency of the number of cases was up to $17 \%$ below the mean. On the other hand, in the months of November, December, January, and February when the rainfall reached a concentration of up to $85 \%$ below the mean, the number of cases increased by up to $26 \%$ (Fig.7).

In the analysis of the correlation between rainfall and the frequency of digestive disorders in cattle, a negative correlation $(\mathrm{r}=-0.70)$ was observed with a coefficient of determination of $0.49 \%$ (Fig. 8 ).

\section{DISCUSSION}

Diseases of the digestive system represented approximately $1 / 4$ of the clinical care of cattle performed at CBG-UFRPE, with a growing increase over the 20 years studied, covering a variety of diseases. The mechanical/motor and fermentative diseases of the forestomach, abomasum, and intestines, which represented approximately $62 \%$ of the cases, stood out due to the characteristics of the productive sector in the region, since the municipalities responsible for the greatest demand for attendance, as well as CBG-UFRPE, are located in the most important milk production region. The increase in the frequency of these diseases over time, highlights the condition of nutritional and metabolic challenge to which farm animals have been subjected in recent decades, due

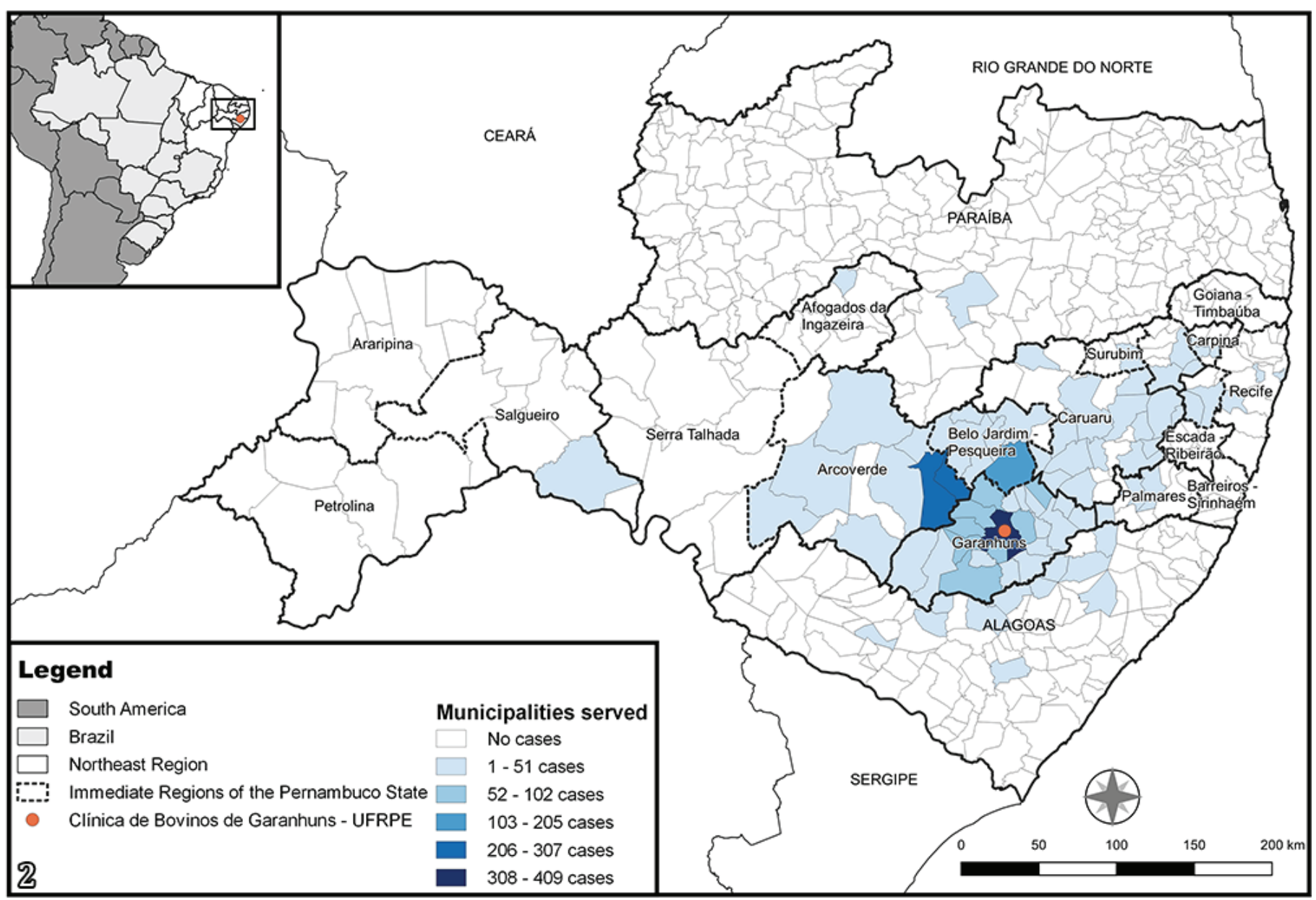

Fig.2. Spatial distribution of the municipalities of origin of the cattle diagnosed with digestive diseases at the "Clínica de Bovinos de Garanhuns”, Campus “Universidade Federal Rural de Pernambuco”, from January 1999 to December 2018. 
to the incessant search for greater productivity. In addition, the difficulties and shortcomings in feed management are clear, which producers still maintain when facing the long periods of drought and scarcity of common feeds in the region (Afonso 2017).

Studies of clinical and epidemiological characterization of diseases that affect the digestive system of cattle in their entirety are scarce in Brazil, especially with the magnitude of the current study in terms of time studied and frequency of cases. In order to establish the occurrence of the main diseases that affect cattle, highlighting the different organic systems, other studies based on clinical cases, showed variation in the frequency of diseases that affect the digestive system of cattle, in different regions of Brazil. However, the number of animals studied, as well as the observation time, were lower than the present study (Tortorelli et al. 2012, Borowsky et al. 2019, Oliveira et al. 2019).

Similar to the current study, mechanical/motor diseases, especially the sequelae of traumatic reticulitis, such as pericarditis and peritonitis, were the most frequently diagnosed disorders of the digestive tract of cattle at HV-UFCG, Paraíba (Marques et al. 2018). On the other hand, in the South, Southeast, and North of the country, tympanism was the most frequent digestive disease among cattle (Tortorelli et al. 2012, Borowsky et al. 2019, Oliveira et al. 2019). The occurrence of traumatic reticulitis and its sequelae is mainly associated with the feed management to which the animals are subjected. Inadequate management and storage of by-products of the local agro-industry (cassava peel and chicken litter) frequently used in the feed of animals may be among the causes of these diseases, in view of reports made by producers about perforating materials that are sometimes found in these by-products (Assis 2019). In addition, the unsatisfactory maintenance of fences and wooden or tire troughs, frequently used in the region, can become a source of foreign bodies such as wire, nails, staples, and steel wires from tires, which are the most common perforating materials found in animals diagnosed with foreign body syndrome (Cramers et al. 2005, Braun et al. 2018a, Marques et al. 2018).

The exposure of animals to this type of material combined with the particularities of the bovine species, such as low selectivity of the ingested food, anatomical and functional constitution of the reticulum, and topographic relations of the abdominal cavity contribute substantially to the development of these diseases (Cramers et al. 2005).

In agreement with this finding, Roth \& King (1991) and Marques et al. (2018) peritonitis (39.2\%), pericarditis (36.1\%), and traumatic splenitis $(10.2 \%)$ were the most common sequelae of traumatic reticulitis. For these authors the perforation caused by metallic foreign bodies in the anterior ventral region of the reticulum, reaching the peritoneum, with the consequent development of local or diffuse peritonitis, as well as perforation of the reticulum that reached the pericardium, leading to the development of chronic lesions of pericarditis and/or fibrinous pericarditis, were the most prevalent sequelae of traumatic reticulitis. Regarding traumatic splenitis, Roth \& King (1991) reported an occurrence lower

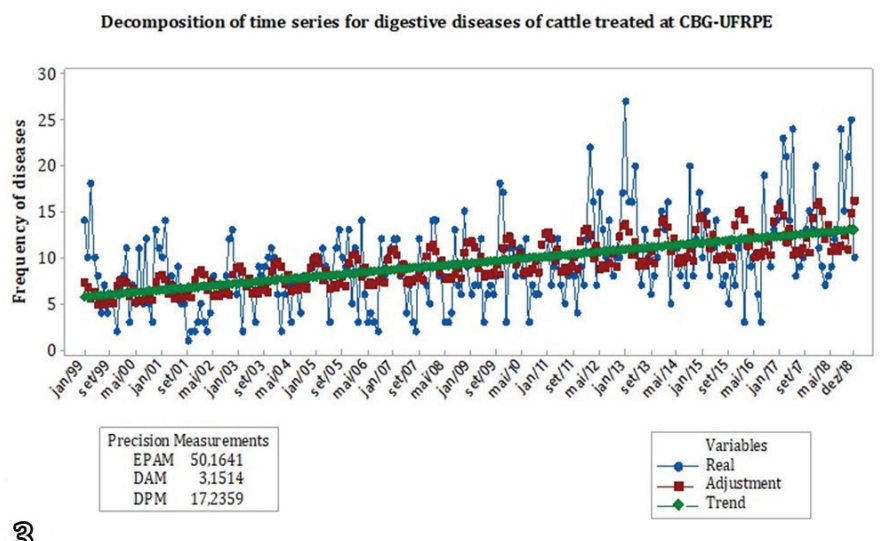

\section{Seasonal indices (Jan.1999/Dec.2018) of the frequency of digestive diseases of cattle treated at CBG/UFRPE}

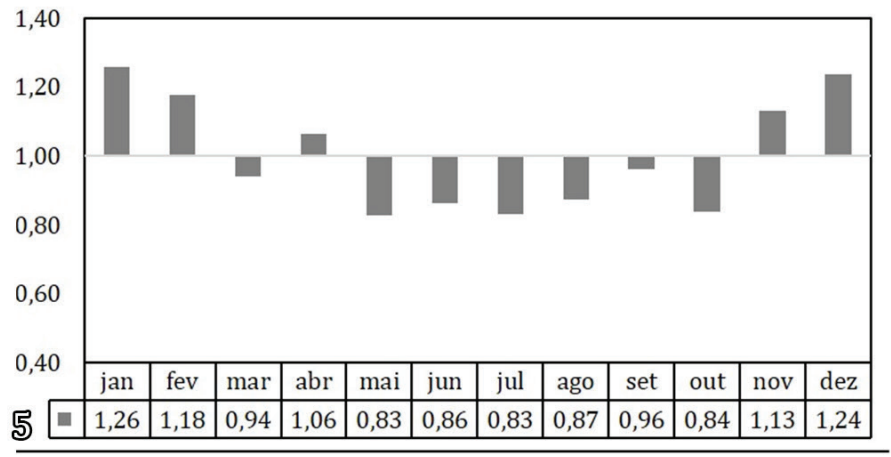

Decomposition of time series of monthly rainfall in the 82893-INMET experimental station (Garanhuns-PE)

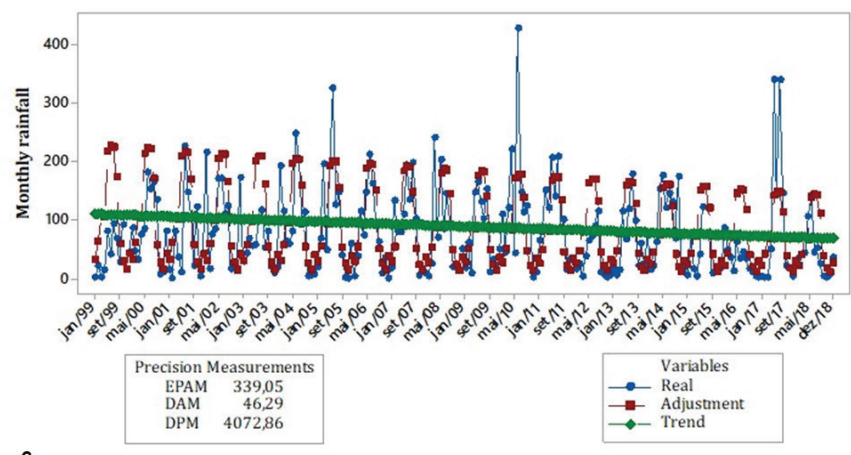

4

Seasonal indices (Jan.1999/Dec.2018) of rainfall measured in the 82893-INMET experimental station (Garanhuns-PE)

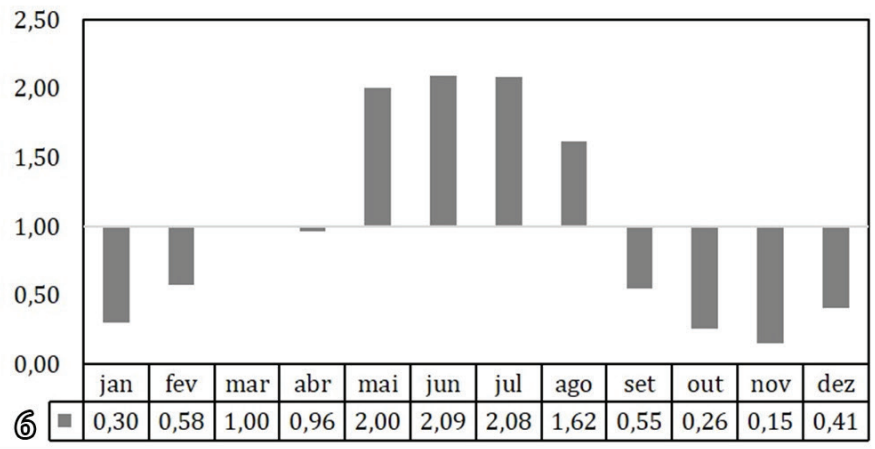

Fig.3-6. (3,5) Decomposition analysis of rainfall index time series in the mediate region of Garanhuns/PE and $(\mathbf{4 , 6 )}$ frequency of digestive disease of cattle diagnosed at CBG-UFRPE from January 1999 to December 2018. 


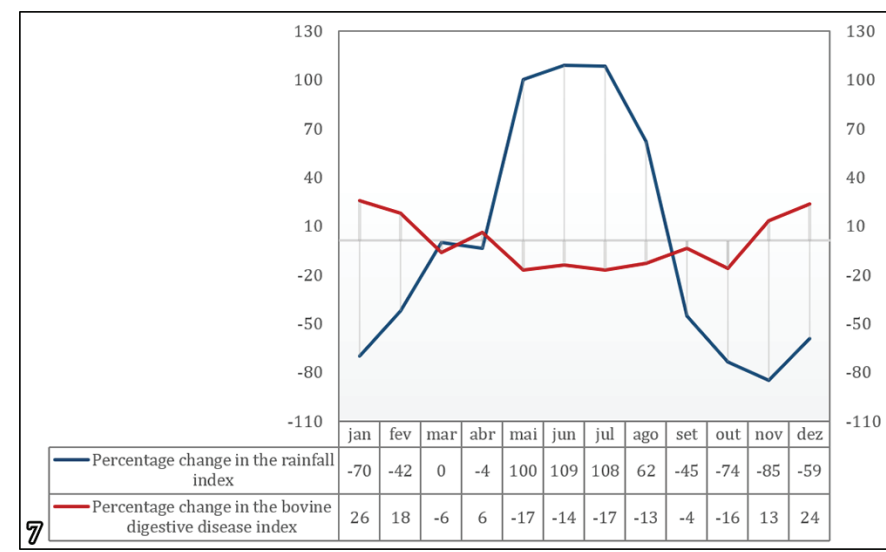

Fig.7. Seasonal analysis of the percentage variation in of the rainfall index in the mediates and immediate regions of the State of Pernambuco and the percentage variation in the index of the number of digestive diseases of cattle diagnosed at CBG-UFRPE from January 1999 to December 2018.

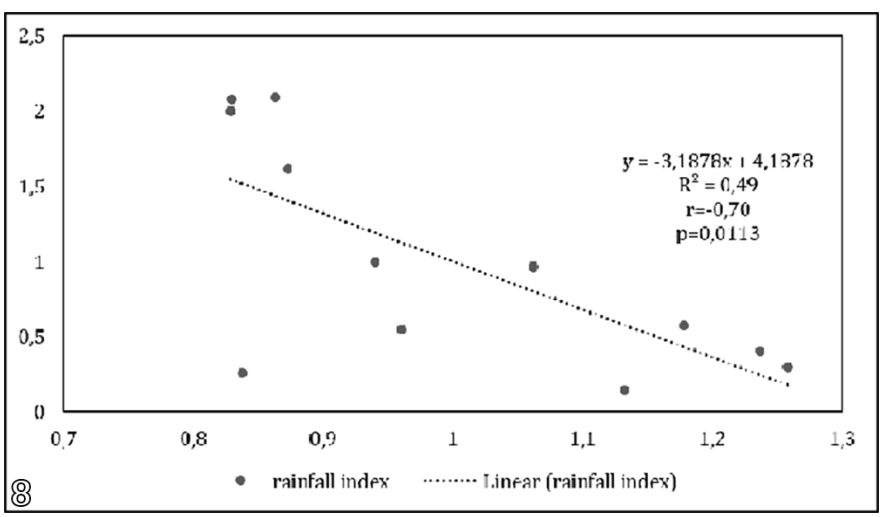

Fig.8. Correlation between pluviometric precipitation in the mediate region of Garanhuns/PE and frequency of digestive disease of cattle diagnosed at CBG-UFRPE from January 1999 to December 2018.

thanthat observed in this study, while Marques et al. (2018) did not report this disease. Although traumatic splenitis is considered uncommon in the ruminant clinic, Silva et al. (2017) found that this condition can represent up to $15 \%$ of the sequelae of traumatic reticulitis.

Complications triggered by traumatic reticuloperitonitis, such as vagus nerve injuries and reticular adhesions are considered the most common causes of vagal indigestion (Dirksen 2005). In the present study, this disease represented approximately $12 \%(90 / 752)$ of mechanical/motor disorders. In addition, $5.5 \%$ of traumatic reticulitis cases had a concomitant diagnosis of vagal indigestion. This disease was also among the most frequent motor disorders of the bovine ruminoreticular cavity diagnosed at the HV-UFCG (Marques et al. 2018), as well as at the Large Animal Clinic of the Veterinary and Animal Sciences University of Punjab, India (Sharma et al. 2015).

Vagal indigestion type IV, which affects cows at the end of pregnancy, was the type most diagnosed, followed by types I, III, and II. In addition, pathological conditions such as peritonitis, pleuritis, tumor lesions (lymphosarcoma and papilloma of the cardia), tuberculosis granulomas, liver abscess, and diaphragmatic hernia were associated with the occurrence of this disease. This result corroborates the findings by Hussain et al. (2017) who point out that although inflammatory lesions and adhesions present in reticuloperitonitis are considered the main causes of vagal indigestion, any other diseases that result in injury, inflammation, or compression of the vagus nerve can cause clinical signs of vagal indigestion. Neoplasia in the cardia or adjacent to gastric compartments and liver abscess associated with clinical cases of anterior functional stenosis and posterior functional stenosis, respectively, have also been described by other authors (Fubini et al. 1985, Gordon 1997). Distension and impaction of the rumen and abomasum in cows at the end of pregnancy have also been associated with a clinical framework of posterior functional stenosis, although there is no direct evidence of the effect of advanced pregnancy on the etiology of this disease (Hussain et al. 2014).

Simple indigestion was the most prevalent fermentative disease and the second most diagnosed digestive disorder. As in the present study, Marques et al. (2018), in Paraíba, also highlighted this disease as the most frequent among the fermentative disorders of the ruminoreticular cavity. During the anamnesis, owners frequently reported sudden changes in the animals' diet, such as an increase in the amount of concentrate, changes in the feed constituents, and accidents such as the invasion of the feed room. Changes in feed management often occur on properties due to the variation in prices and supply of dietary constituents. These changes without prior adaptation are considered the main factors that predispose to this disease, since they cause imbalance in the ruminal microbiota (Afonso \& Borges 2007).

The intestinal and esophageal obstructive diseases were the third most prevalent digestive disorders, representing approximately $9 \%$ of cases each. Intraluminal obstructions caused by phytobezoars were the main cause of obstructive intestinal disorders, representing approximately $1 / 3$ of these, followed by intussusceptions. As in the current study, Marques et al. (2018) found that bovine obstructive intestinal diseases are the most frequent digestive disorders in HV-UFCG, however, intussusception was the most prevalent obstructive intestinal disorder. The formation of phytobezoars within the gastrointestinal tract is often associated with exclusive or high levels of feed rich in non-digestible fiber for a prolonged period. These conditions have been described by Afonso et al. (2008), Hasunuma et al. (2011), Nascimento et al. (2016), and Ubiali et al. (2013) when reporting cases of intestinal obstruction by phytobezoars associated with the supply of forage palm (Opuntia spp.) and elephant grass (Pennisetum purpureum) in an advanced stage of maturity, an exclusive diet of Agave sisalana (sisal) stem, and excessive consumption of Stylosantes sp., legumes, commonly used to feed cattle.

Intraluminal obstruction was responsible for almost all the esophageal obstructive diseases resulting in rupture/ laceration of the esophageal wall in approximately $11 \%$ of cases. For Souza et al. (2011) esophageal rupture was also the main reported complication, which may be related to the handling of animals by unqualified people. The ingestion of fruits such as mango and jackfruit, especially during harvest period, as well as the supply of tubers such as manioc or even palm, of inadequate sizes for the animals' chewing capacity, were among the most common causes of esophageal obstruction, corroborating the findings of Souza et al. (2011). Fruit and tuberous roots are frequent causes of esophageal 
obstruction in cattle in Brazil and worldwide (Panziera et al. 2016, Mandagiri et al. 2017, Pund et al. 2018, Sidhan et al. 2018). However, other less frequent causes, such as the ingestion of plastic bags, pieces of fabric or leather, pieces of bones, and regurgitation of rumen trichobezoars have been described in the literature (Patel \& Brace 1995, Yadav et al. 2008). Factors related to management, such as access of animals to places with fruit trees, especially during the harvest period, accidental contamination of the feed with foreign bodies, and neglect when cleaning the facilities near the corrals or paddocks, may be associated with the occurrence of this disorder (Souza et al. 2011, Panziera et al. 2016).

Nonspecific gastroenteritis, the fourth most prevalent digestive disease, was diagnosed mainly in cattle under the age of one year, especially in calves less than three months of age. This result corroborates Assis-Brasil et al. (2013) who highlighted diarrhea illnesses as the most frequent digestive system disorders in calves. Despite the high frequency of gastroenteritis seen at the hospital, its prevalence on the properties is probably even higher, since this is a herd problem, with other sick animals on the property or the occurrence of deaths being frequently reported by the owners. For Botteon et al. (2008) diarrhea is among the main diseases that affect calves and is often related to inadequate management practices poor feed and environmental hygiene conditions, and, when considering feed management, the origin may be infectious (viral, bacterial, or parasitic) or non-infectious.

Right and left displaced abomasum (RDA and LDA) were the second most frequently diagnosed diseases of a fermentative nature. The proportion between the cases of RDA $(n=81)$ and LDA $(n=43)$ was approximately $2: 1$, this result being in line with that previously reported by Câmara et al. (2010). However, this differs from other hospital surveys that showed a higher frequency of LDA, with a ratio of approximately 4:1 (Rohn et al. 2004, Pentecost et al. 2014). Considering that the etiological factors are the same for both types of DA, the greater degree of severity observed in cases of RDA was undoubtedly a factor that influenced the greater demand for veterinary medical care. For Câmara et al. (2010) the lower frequency of LDA seen at the hospital may be related to the administration of medications to animals on the farm, since calcium solutions are among the medications most administered on the farms. The authors consider that this action may eventually contribute to the resolution of mild cases of LDA, with only those animals for which the treatment used on the property was not successful being sent to the hospital. However, it must be considered that digestive and metabolic diseases are among the main causes of death in high-producing dairy herds and that DA, as well as the low productivity generated by it, are among the main causes of involuntary disposal of cows in these herds (Ollhoff et al. 2008, Silva et al. 2008).

Frothy bloat and ruminal lactic acidosis are among the main diagnosed disorders of fermentative nature, with a similar prevalence, occupying the sixth position among the main diseases of the bovine digestive system. In the region studied, nutritional management, which is commonly used intensively, provides a higher frequency of fermentative digestive disorders. In accordance with Costa et al. (2002) and Coutinho et al. $(2009,2012)$ the consumption of diets with high levels of concentrate was the main factor associated with the development of frothy bloat in the animals studied. In the Northeast the occurrence of frothy bloat in cattle is mainly associated with high levels of concentrate in the animals' diet, and in the South of the country this disease is mainly associated with the consumption of leguminous pastures of the genus Trifolium spp. (Dalto et al. 2009, Ferrão et al. 2015, Noble et al. 2017), confirming the association between management and the types of digestive disorders diagnosed in different regions of the country. Sudden changes in dietary management and an excessive supply of carbohydrates in the diet or accidentally were among the factors associated with the occurrence of rumen lactic acidosis in the animals studied. As previously mentioned, variations in the availability and price of products that make up the animals' diet, especially grains, favor frequent changes in feed management, often without prior adaptation, generating alterations in the rumen microbial population with rapid production of volatile fatty acids and high production of lactic acid (Ortolani et al. 2016). These alterations range from mild cases of simple indigestion to severe cases of ruminal lactic acidosis that often culminate in death.

Impaction of the forestomachs and abomasum are among the main diagnosed diseases of a mechanical/motor nature. A similar frequency of these disorders was described by Marques et al. (2018), in Brasil and Sharma et al. (2015), in India. Low quality fodder, with low levels of digestible protein and energy and high lignin content, such as elephant grass (Pennisetum purpureum) and corn straw in an advanced stage of maturity, as well as low quality alternative sources (sugarcane bagasse, chicken litter) commonly used in the feed of the animals under study, favor the excessive accumulation of ingestion inside the gastric compartments, causing failure in the aboral progression and consequent distension and compression of the affected organ (Borges et al. 2007, Câmara et al. 2009). In addition, other low-quality forages or alternative sources, mainly used in times of scarcity, have been described as a cause of impaction in cattle in Brazil, such as sisal (Agave sisalana), an important source for the production of fiber and used as raw material in the manufacture of ropes and baskets, sunflower silage, produced late and supplied in excess, and banana stem (Musa sp.) supplied as an exclusive diet (Helayel et al. 2012, Mesquita et al. 2012, Nascimento et al. 2016). The size of the forage particles offered to the animals is also considered to be a factor associated with the formation of compact masses in the stomach. Câmara et al. (2009) as well as Hussain et al. (2013) explained that very small particles can lead to faster passage through the rumen-reticulum and cause impaction of the omasum and/or abomasum. On the other hand, Mesquita et al. (2012) and Nascimento et al. (2016) stated that excessively large particles can decrease the rate of passage through the rumen-reticulum, compromising the digestive process of feed carried out by ruminal microorganisms, prolonging the retention time, which generates accumulation undigested food in the forestomach.

Diseases that affect the oral cavity, rectum, and anus, as well as congenital alterations in the digestive system, represented only $8.6 \%$ of the diseases of the bovine digestive system, some diseases stand out in these groups, such as anal atresia, actinomycosis, and actinobacillosis.

Anal atresia was the most frequently diagnosed congenital disease of the digestive system, diverging from studies carried 
out in Rio Grande do Sul and Paraíba where this alteration was reported much less frequently in calves (Dantas et al. 2010, Macêdo et al. 2011, Assis-Brasil et al. 2013). This divergence is probably related to the data sources consulted for carrying out the work, since in the present study clinical records were consulted and the animals often responded well to the treatment of this disease, whereas the previously mentioned works were carried out based on data from animal pathology laboratories.

In the current study, actinomycosis was more frequent than actinobacillosis as also reported by Lucena et al. (2010) in the southern region of the country. Both diseases are related to the ingestion of very fibrous and coarse foods, such as stalks of dry grass or foreign bodies present in the diet. These can cause lesions in the oral mucosa of animals through which microorganisms penetrate the tissues and the disease develops (Andreazza et al. 2013).

In general, diseases of the bovine digestive system had a high lethality rate, close to $50 \%$, as also reported by Marques et al. (2018). This confirms the economic impact of these diseases on the productive system. Among the categories, mechanical/motor diseases presented the highest lethality rate, with emphasis on traumatic reticulitis and its sequelae. The chronic nature of the majority of mechanical/motor diseases contributes substantially to an unfavorable prognosis since, in view of this type of disorder, owners often take longer to seek veterinary medical assistance, which favors therapeutic failure or even makes it unviable to carry out treatment in the hospital unit. Corroborating these findings and considering that success in the treatment of an illness depends on factors such as early diagnosis, diagnostic accuracy, severity of the disease, and adequate therapeutic procedure, Marques et al. (2018) considered that these conditions were responsible for the high lethality observed in cases of peritonitis and traumatic pericarditis. On the other hand, Braun et al. (2018a, 2020) demonstrated that when the diagnosis is made early during the acute phase and without serious complications, traumatic reticuloperitonitis can present a recovery rate of $82 \%$ to $90 \%$ when submitted to conservative or surgical treatment, respectively.

The seasonal fluctuations in rainfall verified by the time series analysis was a significant factor for the occurrence of mechanical/motor disorders and esophageal obstructions. Other authors have also found the influence of seasonality on the occurrence of digestive disorders such as abomasum and forestomach impaction, intestinal obstruction, vagal indigestion, and traumatic reticuloperitonitis (Nuss et al. 2006, Câmara et al. 2009, Mesquita et al. 2012, Hussain et al. 2013, Sharma et al. 2015, Nascimento et al. 2016, Braun et al. 2018a). Although these disturbances can occur at any time of the year, particularly in tropical countries, they are often more prevalent during the dry season, which is the period of scarcity of quality forage, while in the northern hemisphere countries the highest prevalence occurs during the Winter months, when the availability of good quality forage is impaired due to low temperatures.

Despite the strong negative correlation observed between rainfall and the occurrence of digestive disorders, attention is drawn to the coefficient of determination, which demonstrated that the seasonal variation in rainfall does not adjust the regression model well, predicting only half the probability of occurrence of digestive disorders. These results lead us to believe that other factors, not related to rainfall, may also be associated. Câmara et al. (2009), reported that poor management of the sources of roughage used in the animals' diet can promote the appearance of disorders, such as abomasum impaction, even in confined animals and/ or during the rainy season. Braun et al. (2018b) also stated that what defines the relationship between seasonality and the occurrence of digestive diseases, such as traumatic reticuloperitonitis, is the type of management used in each season. As an example, Hasunuma et al. (2011), found no influence of seasonality in the occurrence of cases of intestinal obstruction by phytobezoars resulting from the ingestion of Napier grass. These authors considered that the cause of the disorders was the adopted feed management, characterized by the offer of a large amount of parts of the plant stem that contain higher levels of lignin, regardless of the time of year.

The occurrence of fermentative diseases was not significantly influenced by seasonality, diverging from the findings of Câmara et al. (2010) and Coutinho et al. (2012) who reported its influence on the occurrence of cases of displaced abomasum and frothy bloat, respectively. For these authors, the influence of seasonality is related to the increase in the proportion of fast fermenting carbohydrates (concentrated) in the diet, in periods of low rainfall, and consequent scarcity of good quality forage. However, in the present study it was observed that supplementation of animals with concentrate and industrial by-products, such as cassava peel and "brewery" was carried out in very similar proportions both in the dry season and in the rainy season, which suggests justification for the fact that fermentative disorders are not influenced by seasonality.

To better elucidate the existence of an association between the factors (sex, breed, age, rearing system, and seasonality) and the diseases studied, given the retrospective nature of this study, it is recommended that prospective studies be carried out, which allow the researcher to measure variables more completely and accurately.

\section{CONCLUSIONS}

The occurrence of digestive diseases has been increasing each year, representing a considerable amount of the diseases that affect cattle raised in the most important dairy region of Pernambuco State. Among the diseases, the most frequent are those of a mechanical/motor nature and fermentative of the forestomach, abomasum, and intestines. In addition, the traumatic reticulitis and obstructive intestinal disorders demonstrated the highest lethality rates.

This study confirms the economic and social impact that digestive disorders represent in the cattle production systems and draws attention to the need for health and nutritional guidance work with farmers to minimize these losses.

Acknowledgements.- To the "Coordenação de Aperfeiçoamento de Pessoal de Nível Superior" (CAPES) for financial support. To all the technical and resident veterinarians who make up the CBG and to those who were part of this institution throughout the study period, we appreciate the care in recording the information in the medical records in a way that it became possible to perform this work.

Conflict of interest statement.- The authors declare that there are no conflicts of interest. 


\section{REFERENCES}

Afonso J.A.B. \& Borges J.R.J. 2007. Doenças não transmissíveis do trato digestivo de ruminantes: indigestão simples, p.322-325. In: Riet-Correa F., Schild A.L., Lemos R.A.A. \& Borges J.R.J. (Eds), Doenças de Ruminantes e Equinos. Vol.2. 3를 ed. Palloti, Santa Maria.

Afonso J.A.B. 2017. Afecções intestinais em bovinos. Revta Acad. Ciênc. Anim. 15(Supl.2):15. <http://dx.doi.org/10.7213/academica.15.s02.2017.a03>

Afonso J.A.B., Mendonça C.L., Costa N.A., Souza M.I., Simão L.C.V. \& Dantas F.R. 2002. Alterações clínicas e laboratoriais na dilatação do ceco em bovinos. Análise de 10 casos. Revta Educ. Contin. CRMV-SP 5(3):313-320. <http://dx.doi.org/10.36440/recmvz.v5i3.3298>

Afonso J.A.B., Pereira A.L.L., Vieira A.C., Mendonça C.L., Costa N.A. \& Souza M.I. 2008. Alterações clínicas e laboratoriais na obstrução gastrintestinal por fitobezoários em bovinos. Revta Bras. Saúde Prod. Anim. 9(1):91-102.

Andreazza D., Wouters A.T.B., Watanabe T.T.N., Boabaid F.M., Wouters F., Souza F.S., Souza S.O. \& Driemeier D. 2013. Caracterização patológica e imunohistoquímica das lesões de actinobacilose em bovinos. Pesq. Vet. Bras. 33(3):305-309. <http://dx.doi.org/10.1590/S0100-736X2013000300005>

Assis R.N. 2019. Síndrome do corpo estranho metálico em bovinos: estudo clínico, laboratorial, ultrassonográfico e anatomopatológico. Master's Thesis in Ruminant Health and Reproduction, Universidade Federal Rural de Pernambuco, Garanhuns. 70p.

Assis-Brasil N.D., Marcolongo-Pereira C., Hinnah F.L., Ladeira S.R.L., Sallis E.S.V., Grecco F.B. \& Schild A.L. 2013. Enfermidades diagnosticadas em bezerros na região sul do rio grande do Sul. Pesq. Vet. Bras. 33(4):423-430. <http://dx.doi.org/10.1590/S0100-736X2013000400002>

Bezdekova B.\&JanalikP.2016. Oesophageal disorders in horses: retrospectivestudy of 39 cases. EquineVet. Educ. 30(2):94-99. <http://dx.doi.org/10.1111/eve.12703>

Borges J.R.J., Cunha P.H.J., Moscardini A.R.C., Tortelly R., Franco G.L. \& Silva L.A.F. 2007. Compactação de abomaso em bovinos leiteiros: descrição de cinco casos. Ciênc. Anim. Bras. 8(4):857-862.

Borowsky A.M., Beck C.A.C., Oberst E.R., Rivero B.R.C., Melo L.C., Bueno F.U. \& Loss D.E. 2019. Estudo retrospectivo dos casos clínicos de ruminantes atendidos no Hospital de Clínicas Veterinárias da UFRGS. Acta Scient. Vet. 47:1625. <http://dx.doi.org/10.22456/1679-9216.89623>

Botteon R.C.C.M., Botteon P.T.L., Santos Júnior J.C.B., Pinna M.H. \& Lóss Z.G. 2008. Freqüência de diarréia em bezerros mestiços sob diferentes condições de manejo na região do médio Paraíba, Rio de Janeiro e Minas Gerais. Braz. J. Vet. Res. Anim. Sci. 45(2):153-160. <http://dx.doi.org/10.11606/ issn.1678-4456.bjvras.2008.26712>

Braun U., Gerspach C., Ohlerth S., Warislohner S. \& Nuss K. 2020. Aetiology, diagnosis, treatment and outcome of traumatic reticuloperitonitis in cattle. Vet. J. 255:1-11. <http://dx.doi.org/10.1016/j.tvjl.2020.105424>

Braun U., Warislohner S., Gerspach C., Ohlerth S. \& Nuss K. 2018a. Treatment of 503 cattle with traumatic reticuloperitonitis. Acta Vet. Scand. 60:55. <http://dx.doi.org/10.1186/s13028-018-0410-8> <PMid:30223863>

Braun U., Warislohner S., Torgerson P., Nuss K. \& Gerspach C. 2018b. Clinical and laboratory findings in 503 cattle with traumatic reticuloperitonitis. BMC Vet. Res. 14:66. <http://dx.doi.org/10.1186/s12917-018-1394-3>

Burns L.V., Helayel M.A., Silva M.A.G., Maruo V.M., Córdova F.M., Silva S.L., Barros C.S.L. \& Ramos A.T. 2013. Doenças de animais de produção na região centro-norte do Estado de Tocantins: 85 casos. Arq. Pesq. Anim. 2(1):1-6.

Câmara A.C.L, Afonso J.A.B., Costa N.A., Mendonça C.L., Souza M.I. \& Borges J.R.J. 2010. Fatores de risco, achados clínicos, laboratoriais e avaliação terapêutica em 36 bovinos com deslocamento de abomaso. Pesq. Vet. Bras. 30(5):453-464. <http://dx.doi.org/10.1590/S0100-736X2010000500014>

Câmara A.C.L., Afonso J.A.B., Costa N.A., Mendonça C.L. \& Souza M.I. 2009. Compactação primária do abomaso em 14 bovinos no estado de Pernambuco. Pesq. Vet. Bras. 29(5):387-394. <http://dx.doi.org/10.1590/S0100736X2009000500005>
Câmara A.C.L., Castro M.B., Calado E.B. \& Soto-Blanco B. 2016. Intestinal obstruction caused by neoplasms in two cows. Ciênc. Rural 46(7):12521255. <http://dx.doi.org/10.1590/0103-8478cr20151488>

Costa J.N., Ferreira A.F.M.S.C., Reis M.C., Ferreira M.M., Peixoto A.P.C., Menezes R.V. \& Figueiredo L.J.C. 2002. Timpanismo gasoso e espumoso em bovinos: alterações clínicas e respostas ao tratamento observadas em 39 animais. Anais X Congresso Latino Americano de Buiatria e XXX Jornadas Uruguayas de Buiatría, p.298. (Resumo)

Coutinho L.T., Afonso J.A.B., Costa N.A., Mendonça C.L., Faria P.A.R. \& Soares P.C. 2009. Avaliação da conduta terapêutica em casos de timpanismo espumoso em bovinos. Ciênc. Anim. Bras. 10(1):288-293.

Coutinho L.T., Afonso J.A.B., Costa N.A., Soares P.C. \& Mendonça C.L. 2012. Fatores de risco relacionados à ocorrência do timpanismo espumoso em bovinos criados na Região do Agreste Meridional do Estado de Pernambuco, Brasil. Ciênc. Anim. Bras. 13(3):368-376. <http://dx.doi.org/10.5216/ cab.v13i3.9927>

Cramers T., Mikkelsen K.B., Andersen P., Enevoldsen C. \& Jensen H.E. 2005 New types of foreign bodies and the effect of magnets in traumatic reticulitis in cows. Vet. Rec. 157(10):287-289.<http://dx.doi.org/10.1136/ vr.157.10.287> <PMid:16157571>

Dalto A.G.C., Bandarra P.M., Pedroso P.M.O., Guagnini F.S., Leal J.S., Raymundo D.L. \& Driemeier D. 2009. Timpanismo espumoso em bovinos leiteiros em pastagens de Trifolium spp. (Leg. Caesalpinoideae). Pesq. Vet. Bras. 29(5):401-403. <http://dx.doi.org/10.1590/S0100-736X2009000500007>

Dantas A.F.M., Riet-Correa F., Medeiros R.M.T., Galiza G.J.N., Pimentel L.A., Anjos B.L. \& Mota R.A. 2010. Malformações congênitas em ruminantes no semiárido do Nordeste Brasileiro. Pesq. Vet. Bras. 30(10):807-815. <http://dx.doi.org/10.1590/S0100-736X2010001000002>

Dharmaceelan S., Rajendran N., Nanjappan K., Subramanian M. \& Balasubramaniam G.A. 2012. Incidence of bovine gastrointestinlal obstruction in a Teaching Veterinary Hospital of Tamilnadu, India. Int. J. Vet. 1(3):112-114.

Dirksen G. 1993. Sistema digestivo, p.166-226. in: Dirksen G., Grunder H.D. \& Stober M. (Eds), Rosenberger, Exame Clínico dos Bovinos. $3^{\underline{a}}$ ed. Guanabara Koogan, Rio de Janeiro.

Dirksen G. 2005. Estenosis funcionales entre redecilla y librillo ("síndrome de Hoflund"), p.378-383. In: Dirksen G., Gründer H.D. \& Stöber M. (Eds) Medicina Interna y Cirugía del Bovino. Vol.1. 4⿳ạ ed. Inter-médica, Buenos Aires.

Eshetu E., Tilahun A., Thomas N. \& Awukew A. 2018. Retrospective study on major bovine diseases and financial loss due to treatment in Wolaita Zone: a case of Sodo Zuria District, Southern Ethiopia. IJVHSR 6(1):225229. <http://dx.doi.org/10.19070/2332-2748-1800044>

Ferrão S.A., Costa R.A., Maurique A.P. \& Anjos B.L. 2015. Mortalidade de bovinos por timpanismo espumoso associado a ingestão de Trifolium repens. Anais XLIII Jornadas Uruguayas de Buiatría, Uruguay, p.270-272. (Resumo)

Fubini S.L., Ducharme N.G., Murphy J.P. \& Smith D.F. 1985. Vagus indigestion syndrome resulting from a liver abscess in dairy cows. JAVMA 186(12):12971300. <PMid:4019288>

Gonçalves R.S., Guagnini F.S., Valle S.F., Gonzalez F.H.D. \& Dalto A.G.C. 2018. Aspectos clínicos e laboratoriais de um bovino com deslocamento de abomaso à esquerda. Acta Scient. Vet. 46(Supl.1):349.

Gopal S., Allwin B., Senthil N.R., Vedamanickam S. \& Kumar V.N. 2015. A retrospective study of ailments in goats at Thiruvallur District, Tamil Nadu State. Int. J. Livest. Res. 5(3):26-34. <http://dx.doi.org/10.5455/ ijlr.20150318092127>

Gordon P.J. 1997. Surgical removal of a fibropapilloma from the reticulum causing apparent vagal indigestion. Vet. Rec. 140(3):69-70. <http://dx.doi. org/10.1136/vr.140.3.69> <PMid:9023908>

Hasunuma H., Matsumoto D., Kirino Y., Sasa T., Fushimi Y., Ikeda T., Tshering C. \& Takagi M. 2011. Acute colic possibly caused by phytobezoar derived from napier grass in 5 Japanese black cows reared in the same farm. J. Vet. 
Med. Sci. 73(8):1093-1096. <http://dx.doi.org/10.1292/jvms.10-0449> <PMid:21498963>

Helayel M.A., Ramos A.T., Cordova F.M., Silva M.A.G., Sabino A.J., Barbosa F.B., Moron S.F. \& Burns L.V. 2012. Compactação ruminoabomasal decorrente da ingestão de caule de bananeira (Musa sp.) em bovinos: relato de dois casos. Revta Bras. Ciênc. Vet. 19(3):127-132. <http://dx.doi.org/10.4322/rbcv.2014.094>

Hussain S.A., Uppal S.K., Hussain T., Nabi S.U., Beigh A.S. \& Ashraf S. 2017. Vagus indigestion in bovines: a review in historical perspective. J. Pharm. Innov. 6(12):157-163.

Hussain S.A., Uppal S.K., Randhawa C., Sood N.K. \& Mahajan S.K. 2013. Clinical characteristics, hematology, and biochemical analytes of primary omasal impaction in bovines. Turk. J. Vet. Anim. Sci. 37(3):329-336. <http://dx.doi. org/10.3906/vet-1205-31>

Hussain S.A., Uppal S.K., Sood N.K. \& Mahajan S.K. 2014. Clinico hemato biochemical findings, clinical management, and production performance of bovines with late pregnancy indigestion (Type IV Vagal Indigestion). Vet. Med. Int. 2014:1-6. <http://dx.doi.org/10.1155/2014/525607> <PMid:24804149>

Kachhawa J.P., Singh A.P., Kachhawaha S., Tanwar R.K., Ahuja A. \& Gahlot T.K. 2019. Retrospective study of diseases of camel at teaching veterinary clinical complex of RAJUVAS, bikaner. Isr. J. Vet. Med. 74(4):177-183.

Lawson-Ananissoh L.M., Bouglouga O., Bagny A., El-Hadji Y.R., Kaaga L. \& Redah D. 2018. Digestive diseases in elderly and factors associated with length of stay in the hepatology and gastroenterology unit of the campus teaching hospital of lome (Togo). Arq. Gastroenterol. 55(4):369-374. <http://dx.doi.org/10.1590/s0004-2803.201800000-80>

Lira M.A.A., Simões S.V.D., Riet-Correa F., Pessoa C.M.R., Dantas A.F.M. \& Miranda Neto E.G. 2013. Doenças do sistema digestório de caprinos e ovinos no semiárido do Brasil. Pesq. Vet. Bras. 33(2):193-198. <http://dx.doi.org/10.1590/S0100-736X2013000200010>

Little T.M. \& Hills F.J. 1978 Agricultural Experimentation: design and analysis. John Wiley and Sons, New York. 350p.

Lucena R.B., Pierezan F., Kommers G.D., Irigoyen L.F., Fighera R.A. \& Barros C.S.L. 2010. Doenças de bovinos no Sul do Brasil: 6.706 casos. Pesq. Vet. Bras. 30(5):428-434. <http://dx.doi.org/10.1590/S0100-736X2010000500010>

Macêdo J.T.S.A., Lucena R.B., Giaretta P.R., Kommers G.D., Fighera R.A., Irigoyen L.F. \& Barros C.S.L. 2011. Defeitos congênitos em bovinos da Região Central do Rio Grande do Sul. Pesq. Vet. Bras. 31(4):297-306. <http://dx.doi.org/10.1590/S0100-736X2011000400005>

Mandagiri S.B., Gaddam V., Podarala V. \& Kumar R.V.S. 2017. Surgical management of cervical choke in a cow - a case report. Int. J. Livest. Res. 7(2):215-217. <http://dx.doi.org/10.5455/ijlr.20170209071928>

Marques A.L.A., Aguiar G.M.N., Lira M.A.A., Miranda Neto E.G., Azevedo S.S. \& Simões S.V.D. 2018. Enfermidades do sistema digestório de bovinos da região semiárida do Brasil. Pesq. Vet. Bras. 38(3):407-416. <http://dx.doi org/10.1590/1678-5150-PVB-4633>

Mesquita L.P., Abreu C.C., Nogueira C.I., Pavarini S.P., Seixas J.N., Varaschin M.S., Bezerra Júnior P.S. \& Wouters F. 2012. Surto de compactação primária de abomaso em bovinos leiteiros associado ao consumo de silagem de girassol. Pesq. Vet. Bras. 32(6):510-514. <http://dx.doi.org/10.1590/ S0100-736X2012000600007>

Nascimento E.M., Medeiros R.M.T., Simões S.V.D. \& Riet-Correa F. 2016 Compactação ruminal e obstrução intestinal em bovinos, associadas ao consumo de Agave sisalana Perrine (Agavaceae). Pesq. Vet. Bras. 36(8):719723. <http://dx.doi.org/10.1590/S0100-736X2016000800007>

Noble J.M., Maciel M.A.P., Oliveira C.S.V., Hoppen L.P. \& Risch A.L.C. 2017. Timpanismo espumoso em terneiros no município de Hulha Negra: relato de caso. Anais da 14º Mostra de Iniciação Científica. Urcamp, Bajé, p.146.

Nuss K., Lejeune B., Lischer C. \& Braun U. 2006. Ileal impaction in 22 cows. Vet. J. 171(3):456-461. <http://dx.doi.org/10.1016/j.tvjl.2005.02.024> $<$ PMid:16040260>
Oliveira M.C., Ramos A.T., Cunha I.M., Nunes G.S., Chenard M.G., Nogueira V.D.A., Caldas S.A. \& Helavel M.A. 2019. Enfermidades de bovinos e ovinos diagnosticadas no Estado do Tocantins. Acta Scient. Vet. 47:1676. <http:// dx.doi.org/10.22456/1679-9216.95717>

Ollhoff D.R., Rogalsky A.D., Grebogi A.M., Almeida R., Ostrensky A. \& Souza F.P. 2008. Causas de descarte e óbito de bovinos leiteiros entre 2000-2006 em um rebanho de alta produção. Revta Acad. Ciênc. Agrár. Ambient. 6(3):381-387. <http://dx.doi.org/10.7213/cienciaanimal.v6i3.10616>

Ortolani E.L., Sousa R.S., Oliveira F.L.C., Minami N.S. \& Dias M.R.B. 2016. Prevenção das acidoses ruminais em rebanhos leiteiros: novos conceitos. Ciênc. Vet. Tróp. 19(3):113-117.

Panziera W., Konradt G., Bassuino D.M., Gonçalves M.A. \& Driemeier D. 2016. Timpanismo em bovinos, secundário à obstrução esofágica por Citrus limon (limão siciliano). Pesq. Vet. Bras. 36(5):397-400. <http://dx.doi. org/10.1590/S0100-736X2016000500007>

Patel J.H. \& Brace D.M. 1995. Esophageal obstruction due to a trichobezoar in a cow. Can. Vet. J. 36(12):774-775. <PMid:8748449>

Pawaiya R.V.S., Singh D.D., Gangwar N.K., Gururaj K., Kumar V., Paul S. Sharma N., Mishra A.K., Kumar A., Sharma D.K. \& Singh S.V. 2017. Retrospective study on mortality of goats due to alimentary system diseases in an organized farm. Small Ruminant Res. 149:141-146. <http://dx.doi.org/10.1016/j. smallrumres.2017.02.007>

Pentecost R.L., Niehaus A.J., Anderson D.E., Miesner M.D. \& Rings D.M. 2014. Outcome following surgical correction of abomasal displacement in lactating dairy cattle: a retrospective study of 127 cases (1999-2010). J. Vet. Sci. Anim. Husb. 2(1):1-5. <http://dx.doi.org/10.15744/2348-9790.1.402>

Pund S., Chattar V. \& Netake P. 2018. A surgical approach for oesophageal choke in a crossbred cow. Int. J. Environ. Sci. Technol. 7(5):1662-1665.

Pupin R.C., Leal P.V., Paula J.P.L., Guizelini C.C., Möck T.B.M., Lemos R.A.A. \& Gomes D.C. 2019. Cattle diseases in Mato Grosso do Sul, Brazil: a 24-year survey (1995-2018). Pesq. Vet. Bras. 39(9):686-695. <http://dx.doi. org/10.1590/1678-5150-pvb-6384>

Rohn M., Tenhagen B.A. \& Hofmann W. 2004. Survival of dairy cows after surgery to correct abomasal displacement: 1 . Clinical and laboratory parameters and overall survival. J. Vet. Med. A, Physiol. Pathol. Clin. Med. 51(6):294-299. <http://dx.doi.org/10.1111/j.1439-0442.2004.00649.x> <PMid:15485565>

Rondelli L.A.S., Silva G.S., Bezerra K.S., Rondelli A.L.H., Lima S.R., Furlan F.H., Pescador C.A. \& Colodel E.M. 2017. Doenças de bovinos em Mato Grosso diagnosticadas no Laboratório de Patologia Veterinária da UFMT (2005-2014). Pesq. Vet. Bras. 37(5):432-440.<http://dx.doi.org/10.1590/ S0100-736X2017000500002>

Roth L. \& King J.M. 1991. Traumatic reticulitis in cattle : a review of 60 fatal cases. J. Vet. Diagn. Investig. 3(1):52-54. <http://dx.doi. org $/ 10.1177 / 104063879100300111><$ PMid:2039788>

Santos G.A., Marcondes J.G.R., Curti J.M. \& Pereira P.F.V. 2017. Doenças do sistema digestório de pequenos ruminantes no norte do Paraná. Revta Acad. Ciênc. Anim. 15(Supl.2):139-140. <http://dx.doi.org/10.7213/ academica.15.s02.2017.69>

Sharma A.K., Dhaliwal P.S. \& Randhawa C.S. 2015. Epidemiological studies on forestomach disorders in cattle and buffaloes. Vet. World 8(9):1063-1067. <http://dx.doi.org/10.14202/vetworld.2015.1063-1067><PMid:27047199>

Sidhan R., Kumaresan A. \& Dharmaceelan S. 2018. Surgical management of caudal thoracic esophageal obstruction in a cross - Bred cow. Indian Vet. J. 95(3):65-66.

Silva Filho A.P., Afonso J.A.B., Souza J.C.A., Costa N.A. \& Mendonça C.L. 2010. Análise clínica e patológica em 20 casos de intussuscepçõ em bovinos. Vet. Zootec. 17(3):421-430.

Silva Filho A.P., Afonso J.A.B., Souza J.C.A., Dantas A.C., Costa N.A. \& Mendonça C.L. 2012. Achados clínicos de bovinos com úlcera de abomaso. Vet. Zootec. 19(2):196-206. 
Silva L.A.F., Coelho K.O., Machado P.F., Silva M.A.M., Moura M.I., Barbosa V.T., Barbosa M.M. \& Goulart D.S. 2008. Causas de descarte de vacas da raça Holandesa confinadas em uma população de 2.083 bovinos (2000-2003). Ciênc. Anim. Bras. 9(2):383-389.

Silva T.V., Afonso J.A.B., Mendonça C.L., Costa N.A., Silva N.A.A., Souto R.J.C., Coutinho L.T., Souza J.C.A. \& Cajueiro J.F.P. 2017. Esplenite traumática em bovinos - relato de 16 casos. Revta Acad. Ciênc. Anim. 15(Suppl.2):299-300. <http://dx.doi.org/10.7213/academica.15.s02.2017.149>

Souza M.I., Afonso J.A.B., Costa N.A., Coutinho L.T. \& Silva Filho A.P. 2011. Estudo retrospectivo dos caso de ostrução esofágica por corpo estranho em ruminantes atendidos na Clínica de Bovinos, Campus Garanhuns/ UFRPE, entre os anos de 1980-2010. Vet. Zootec. 18(4 Supl.3):269-272.
Thrusfield M. 2005. Veterinary Epidemiology. 3rd ed. Blackwell Science, Oxford. 610p.

Tortorelli G., Padilha J., Mendes G. \& Gregory L. 2012. Atendimento a criatórios de bovinos e pequenos ruminantes localizados na grande São Paulo. Revta Cult. Ext. USP 8:125-137. <http://dx.doi.org/10.11606/issn.2316-9060. v8i0p125-137>

Ubiali D.G., Silva R.G.F., Oliveira L.P., Moraes L.G., Caldeira F.H.B., Pescador C.A., Souza M.A. \& Colodel E.M. 2013. Obstrução intestinal em bovinos associada ao consumo de Stylosanthes sp. (Fabaceae Papilionoideae). Pesq. Vet. Bras. 33(2):148-154. <http://dx.doi.org/10.1590/S0100-736X2013000200003>

Yadav G.U., Thorat M.G., Somwanshi A.G. \& Talekar M.J. 2008. Thoracic oesophageal obstruction in a Marathwadi buffalo. Vet. World 1(5):149. 